\title{
Analysis on Evolutionary Sequence of Bauxite Ore in the Wuchuan-Zheng' an -Daozhan area, Northern Guizhou, China
}

\author{
Tao Cui \\ College of Resources and Environmental Engineering, Guizhou Institute of \\ Technology, Guiyang, 550003, China \\ cuitao1203@163.com
}

\begin{abstract}
Bauxite ore in the Wuchua-Zheng, an-Daozhan area, Northern Guizhou Province can be divided into 4 basic types: massive bauxite, clastic bauxite, oolithic bauxite and earthy bauxite. We find the four ores are kept in a continuous evolution from our comprehensive analysis on bauxite color, texture, composition and elements though they differ largely in texture and composition. Massive bauxite is the basic form of bauxite ore, earthy bauxite is the final form, and the basic evolutionary sequence of bauxite ore is: massive $\rightarrow$ clastic $\rightarrow$ oolithic $\rightarrow$ earthy or it can directly evolve from massive bauxite or clastic bauxite into earthy bauxite without oolithic bauxite process.
\end{abstract}

Keywords: bauxite, ore evolution, earthy bauxite, Wuchuan-Zheng, an-Daozhan area

\section{Introduction}

The Wuchuan-Zheng'an- Daozhan area of Northern Guizhou Province is rich in bauxite resources and many experts and scholars have carried out research on them which has helped to determine the source and mineral composition of bauxite [1-4], demonstrate element migration rule [5-8], identify metallogenic environment and process of bauxite [9-13], and establish metallogenic model of bauxite [14]. Abundant though the former researches have been, and the analysis on the relationship of the four basic ore types shall be further carried out. Whether the four types are evolving into ores independently or in a progressive evolution sequence during bauxite metallogenic process. This paper has discussed the evolution relationship among different bauxite ores based on the comprehensive analysis on their color, texture, composition and other features.

\section{Geological Setting}

WZD bauxite is located in Wuchuan, Zheng'an and Daozhen County, northern Guizhou, which is an important part of centre Guizhou-southern Chongqing bauxite belt [15]. The regional tectonics position of the study area is in the fold belt in northern Guizhou of the upper Yangtze Block [16]. From the oldest to the youngest, the main strata in WZD area includes Cambrian, Ordovician, Silurian, Permian, Triassic and Jurassic. Cambrian is mainly distributed in the core of anticlines, Triassic and Jurassic are mainly distributed in the core of synclines. Bauxite underlies the LiangShan formation $\left(\mathrm{P}_{2} \mathrm{l}\right)$ or Qixia formation $(\mathrm{P} 2 \mathrm{q})$ in the middle Permian, and overlies the HuangLong formation (C2h) of upper Carboniferous or the Hanjiadian formation of the lower Silurian (S1hj). The bauxite is stratiform and unconformable with the underlying and overlying strata. Fig. 1 shows that the distribution of the bauxite is controlled by nine synclines. Thickness of the bauxite is $0.68-15.7 \mathrm{~m}$, and its profile can be divided into two lithology parts: the upper part and the lower part $[12,13]$. The former is aluminous rock, dominated by high grade bauxite or half grade bauxite; the latter is low grade bauxite. According to the lithological and textural properties, the natural types of bauxite deposit can roughly be 
subdivided into four categories: massive bauxite, oolithic bauxite, clastic bauxite and earthy bauxite [1,12]. Different types of ore was saved in different position of section (Fig.2), almost all the high grade bauxite ore is located in the upper part of the section. In the whole not only different location of section has different types of bauxite ore, but also the same type bauxite ore in the different position has different structure, such as massive bauxite in the upper part has the more loose structure and the lighter color than massive bauxite in the lower part of the section (Fig.2).

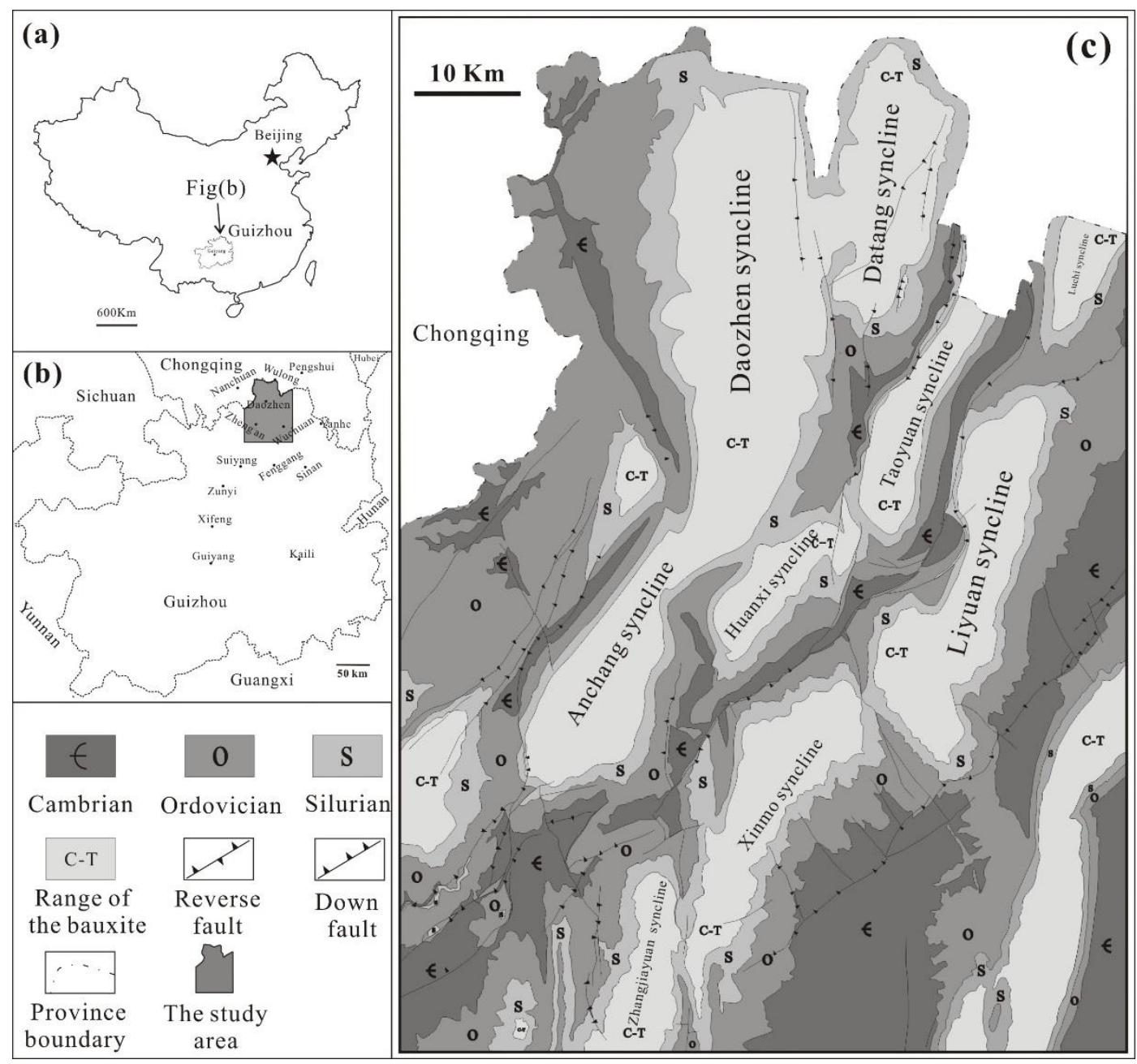

Figure 1. (a)Locality Map of Guizhou,(b)The Map Showing the Location of the Study Area,(c)Geology Map of the WZD Area in Northern Guizhou (Cited from:[5,12-13]) 


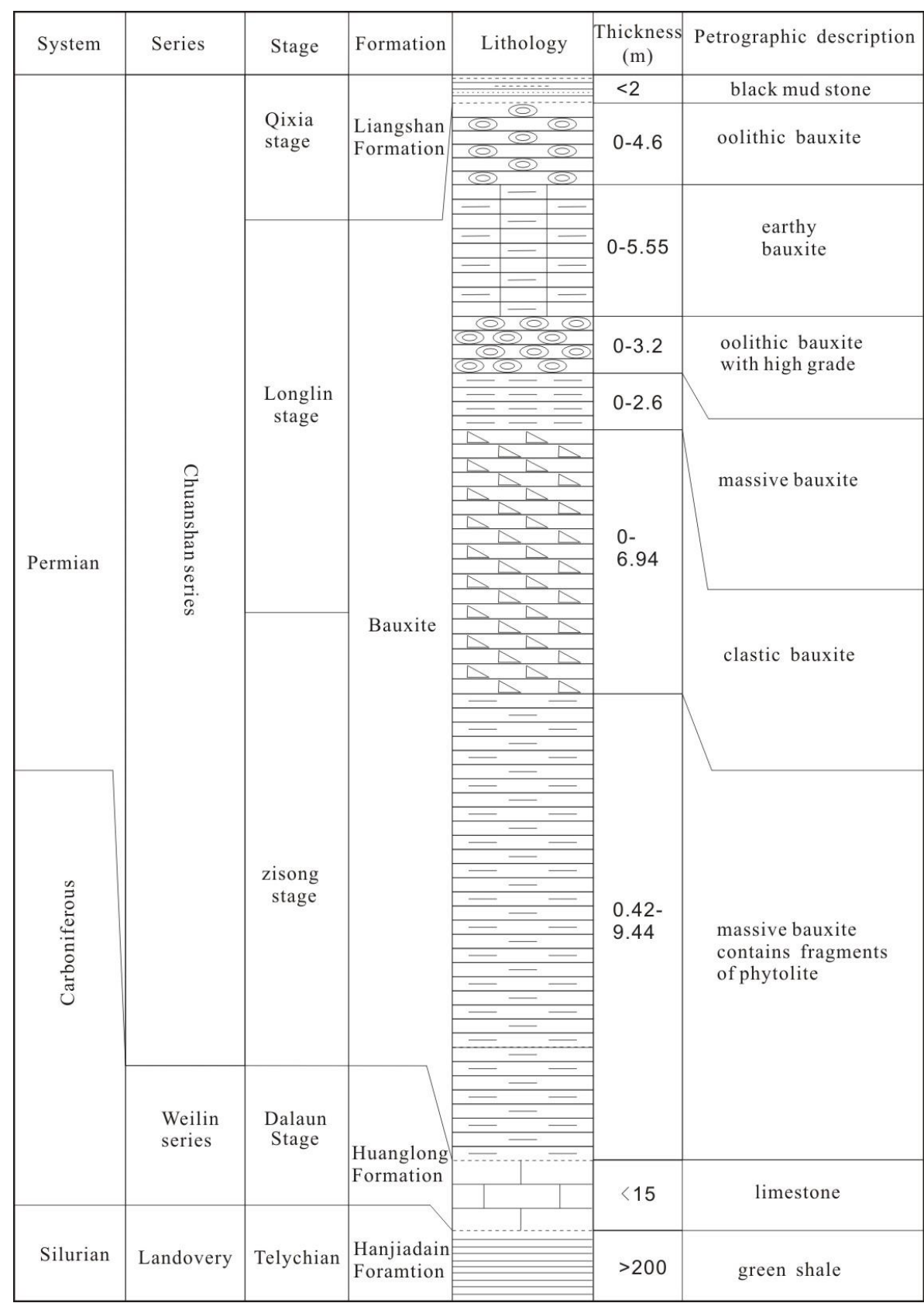

Figure 2. Column Shows the Location of Different Types of Ore (Cited from [13])

\section{Original Form of Bauxite Ore}

Laterization process is an indispensable process for bauxite formation. Metallogenic material of parent rock after laterization process mainly includes kaolinite, hematite, and part of diaspora [17-18]. Hanjiadian formation shale, Huanglong formation limestone and other rocks provide source for bauxite promotion in the Wuchuan, Zhengan and Daozhan Counties of Northern Guizhou Province [3-4, 19], those parent rocks after laterization process provide ore-forming materials for bauxite in the Wuchuan, Zhengan and Daozhan Counties of Northern Guizhou Province, which will be deposited in low energy and reducing environment through colloid transport and suspended-load transport $[9,12,20$ 21]. Fine-grained ore-forming material will be deposited in ore-forming basins through transport, therefore, there are a small number of fragment content in original sediment, 
mainly are gunk mainly composed of clay mineral including kaolinite, illite and so forth, and part of kaolinite may transform into chlorite after the reaction with $\mathrm{Mg} 2+$ in sea water during transport and deposition. According to the deduction, the ore-forming parent rock shall have been clay rock if it is directly compacted into rock without other transformation effects after deposition. And the clay rock will transform into massive bauxite when its Al2O3 mass fraction is higher than $40 \%$. Therefore, the initiate state of most ores in the Wuchuan, Zhengan and Daozhan Counties shall be clay rock or clay rock whose color, texture and composition are similar to massive bauxite. Initial state of ores is of gunk structure with low clastic particle content, and the color is light grey-grey green, low $\mathrm{Al} 2 \mathrm{O} 3$ content $[1,12]$.

\section{Characteristics of Different Types of Ores}

Bauxite is a rather broad concept and the standard of bauxite ore changes as world situation and economy changes. When economic situation is good or the market has great demand, low-grade bauxitic rock can also be used as bauxite. Bauxite ore here discussed has researched industrial grade, and in the meanwhile, due to the continuity of ore evolution, here we also discuss part of bauxitic rock or clay rock not reaching industrial grade.

Massive bauxite ore is the initiate state for bauxite ore evolution, the ore is compact, hard, low-grade, low impurity content (Fig.3, a). Massive bauxite ore will transform into massive bauxitic rock when its $\mathrm{Al} 2 \mathrm{O} 3$ content is lower than $40 \%$, or further transform into ordinary chlorite or kaolinite clay rock when $\mathrm{Al} 2 \mathrm{O} 3$ content keeps on decreasing. Clastic bauxite ore is characterized by abundant coarse-grained clastic, clastic particles diameter varies from $\mathrm{mm}$ to $\mathrm{cm}$. In clastic ores, diaspore exists in the form of matrix, and the particles are mainly composed of kaolinite and chlorite (Fig.3, b). Oolithic bauxite contains oolith and pisolite with concentric layer structure. The matrix of oolithic bauxite ore is diaspore, oolithic concentric layer has diaspore and clay mineral, such as mixedlayer of diaspore and chlorite (Fig.3; Fig.4, a). Earthy bauxite also has gunk structure, light grey to white, the lighter color, the highers the grade (Fig.3, d). Earthy bauxite ore has the lowest $\mathrm{Si}$ and Fe content [12], in particular, Fe content is far lower than that in other types of bauxite ores, which shows that iron-removal effect that earthy bauxite undergoes is the most powerful one and ore-forming reformation on earthy bauxite ore is the greatest.

Through the comparison of the four types of bauxite ores we could find that (Fig.3, Fig.4) the following rules are among the ores (table.1): 1) the deeper the color, the lower the grade; 2) the compacter the ore, the lower the grade; soft porous ores have higher grade; 3 ) ore with uniform texture has higher grade, ore of complex composition has low grade. According to the above analysis, the color, texture and other characteristics of massive bauxite are consistent with that of low-grade ores, while attributive characteristics of earthy bauxite are consistent with that of high-grade bauxite ores. Clastic and oolithic bauxite are mainly dependent on clastic content, the higher the clastic and oolith content, the lower the grade, or high-grade bauxite ores. While oolithic bauxitic rock/bauxite usually have low $\mathrm{A} 12 \mathrm{O} 3$ content and they tend to have higher-grade (Fig.3, c) once they reach ore standards, in that the formation of oolithic bauxite needs to undergo stronger leaching process during which the matrix and oolith of oolithic bauxite ore will be transformed and the matrix after transformation is turning into diaspore, while impurity compositions in oolith reduce significantly, diaspore content increases, part of ore oolith only leaves residual texture, which makes oolithic bauxite be of low-grade and once reaching industrial grade be of higher-grade. 

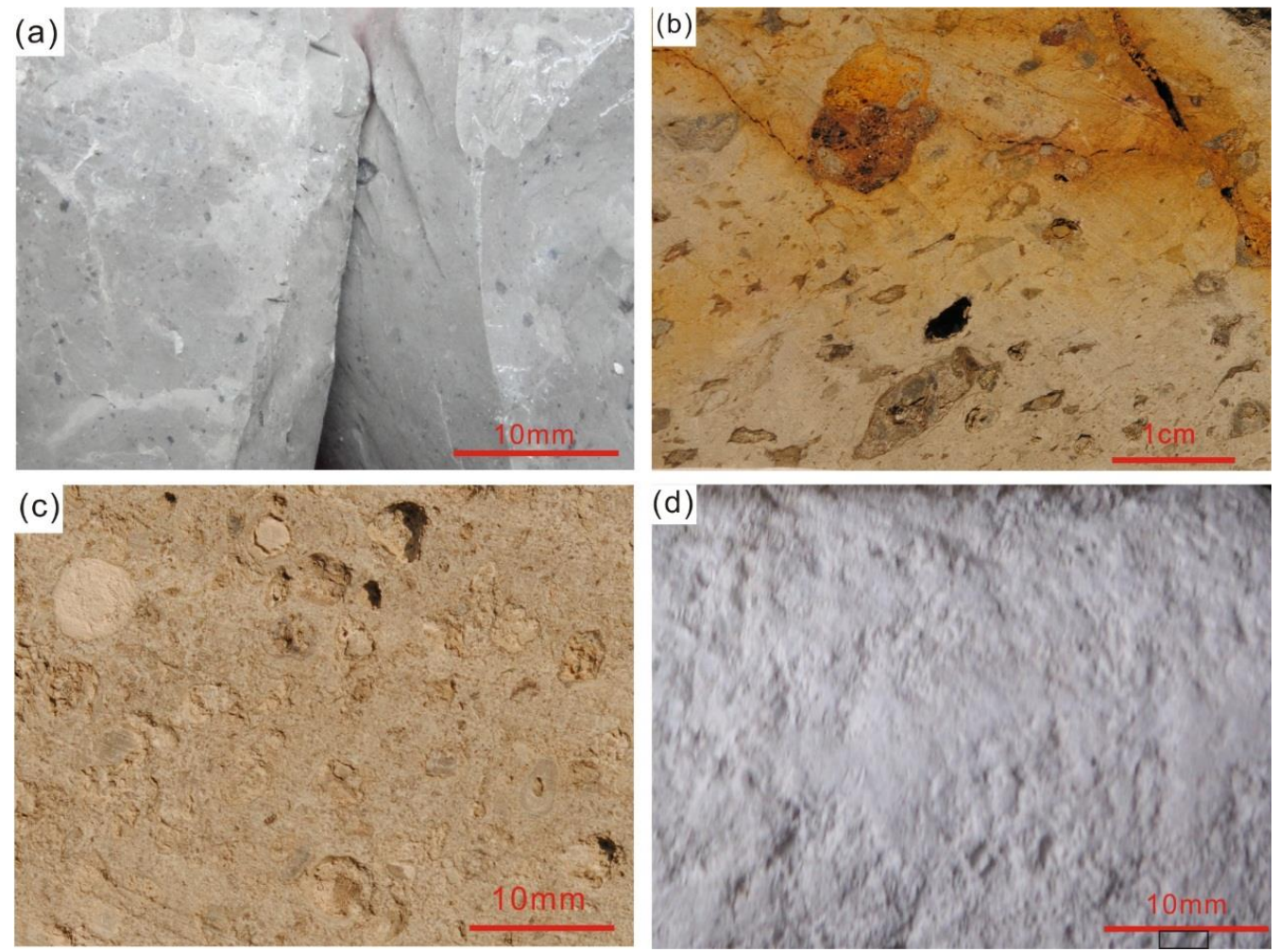

Figure 3. Characteristics of Different Types of Ore (a Cited from [13]; d Cited from [12]) a.Massive Bauxite; b.Clastic Bauxite; c. Oolitic Bauxite; d. Earthy Bauxite

Table 1. Features Comparison of Different Types of Ore

\begin{tabular}{|c|c|c|c|c|}
\hline & Massive ore & Clastic ore & Oolithic ore & Earthy ore \\
\hline Color & Grey & Light grey & Light grey & $\begin{array}{l}\text { Light grey to } \\
\text { white }\end{array}$ \\
\hline Porosity & Small & Medium & Medium & big \\
\hline $\begin{array}{l}\text { Clastic/oolit } \\
\text { h content }\end{array}$ & Low & $\begin{array}{l}\text { High, content } \\
\text { lowers as grade } \\
\text { increases }\end{array}$ & $\begin{array}{l}\text { High, content } \\
\text { lowers as grade } \\
\text { increases }\end{array}$ & Hardly any \\
\hline Grade & Low & Medium & Relatively high & Rather high \\
\hline
\end{tabular}



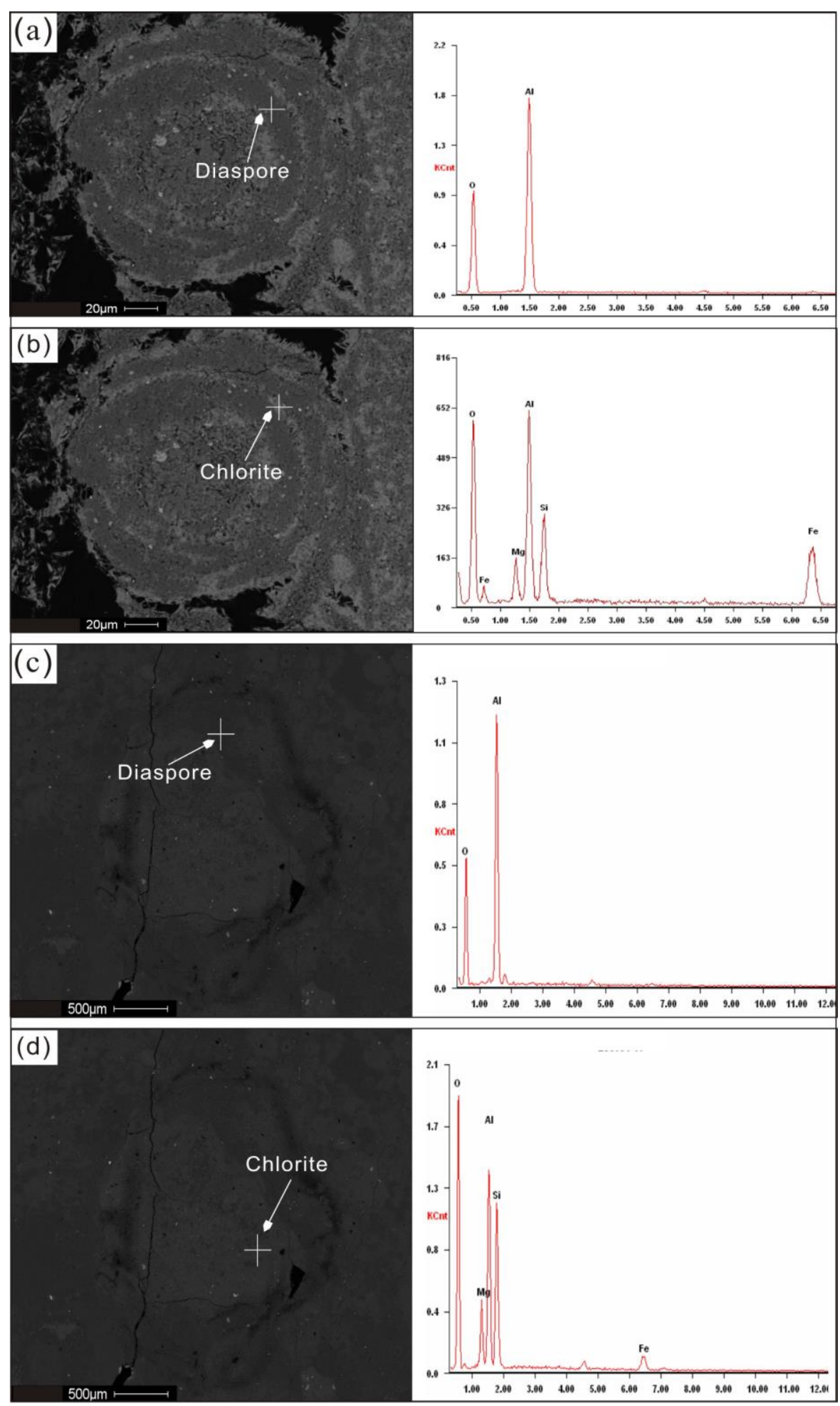

Figure 4. Composition and Characteristics of Oolith and Clastic Particle (Scanning Electron Microscope): a,b. Oolith; c, Composition of Matrix in Clastic Bauxite Ores d. Composition of Clastic Particle in Clastic Bauxite Ores 


\section{Evolutionary Relationship of Different Types of Ore}

Instead of deposition reason, the bauxite ores in the Wuchuan, Zhengan and Daozhan Counties of Northern Guizhou Province undergo leaching transformation after deposition and then a large amount of desilicication iron-removal makes the formation of high-grade bauxite ore [21]. And the formation of the four types is all following the process. The texture and composition of ore-forming material after deposition and consolidation will get close to massive bauxite, while the massive bauxite has higher Al2O3 content, which illustrate that leaching process has taken place onto massive bauxite. After formation the massive bauxite or clay rock will be broken into clastic particles by hydrodynamic force which is mainly composed of clay mineral (Fig.4, d) including chlorite and kaolinite, in a few cases is diaspore, and the existence of clastic particles reduces the grade of bauxite ore. The clastic particles are argillaceous and will be ground after a short-distance transport in the basin to cause the mixed preservation of broken particles and ground particles which undergo leaching process together and finally give birth to clastic bauxite. Therefore, calstic bauxite is evolving from massive bauxite or clay rock, and the clastic particles are clastics forming in the basin. The formation of oolithic bauxite is relatively complex, from the perspective of preservational characteristics of oolith (including pisolite), the formation of oolith is closely related to clastic, and the ore-forming oolith shall be evolving from differential leaching process of clastic, though the causes of oolith are not clearly determined, oolithic bauxite shall develop from clastic bauxite. Earthy bauxite is the final evolutionary form of bauxite ore, massive ores, clastic ores, oolithic ores can all evolve into earthy ores. The complete ore evolutionary sequence in the Wuchuan, Zhengan and Daozhan Counties, Northern Guizhou Province is: massive $\rightarrow$ clastic $\rightarrow$ oolithic $\rightarrow$ earthy ores. The complete evolutionary sequence of bauxite ore can be divided into 4 stages, but it doesn't mean that all bauxite ores in the Wuchuan, Zhengan and Daozhan Counties shall undergo the 4 stages. Massive ores can be directly transformed into earthy ore after formation if it is uninfluenced by hydrodynamic force and continues to be in leaching process. Clastic ores will not evolve into oolith or pisolite after leaching process and gives direct birth to earthy ores.

\section{Summary}

The following conclusions can be drawn from above comprehensive analysis: 1) clay rock or massive ores are the initiate state of ores in the Wuchuan, Zhengan and Daozhan Counties of Northern Guizhou Province, earthy ores are the final state for ore evolution; 2 ) the type of bauxite ore is closely related to ore grade, the color, texture, grade and other characteristics of different ores could reflect the evolutionary relationship among those ores; 3 ) in clastic or earthy bauxite ore, the lower content of clastic or pisolite content, the higher grade, which shows that the formation of high-grade bauxite is a process related to clastic and pisolite removal; 4 ) ore complete evolutionary sequence is massive $\rightarrow$ clastic $\rightarrow$ oolithic $\rightarrow$ earthy ore, while both massive ore and clastic ore can be directly transformed into earthy ores.

\section{Acknowledgment}

This work was supported by the provincial project of characteristics of REE and its transferring disciplinarian in mineralizing process of the bauxite in northern Guizhou, China (No.LH[2014] 7358), the project of analysis on geochemical behaviors of Platinum group elements in Emeishan basalt (No.XJGC 20131204), Guizhou Institute of Technology, Guiyang, 550003, China. 


\section{References}

[1] G. Wu, Z. Jin, M. Bao and Z. Mao, "Bauxite metallogenic regularly in the Wuchuan- Zheng' an Daozhen Area, Northern Guizhou", Geology and Prospecting, vol. 44, no. 6, (2008), pp. 31-35.

[2] Z, Jin, G. Wu, Y. Zhao and M. Bao, "The geochemical characteristics of Wachangping bauxite deposite in Wuchuan County, Guizhou Province, China", Acta mineralogical sinica, vol. 29, no. 4, (2009), pp. 458-462.

[3] Z. Zhao, D. Wang, P. Li and Z. Lei, "Detrital zircon U-Pb geochronology of the Dazhuyuan formation in northern Guizhou: implication for bauxite mineralization", Rock and Mineral Analysis, vol. 32, no. 1, (2013), pp. 166-173.

[4] W. Yu, Y. Du, Q. Zhou, Z. Jin, X. Wang, Y. Qin and T. Cui, "Provenance of bauxite beds of the lower Permian in Wuchuan- Zheng,an- Daozhen area, northern Guizhou province: evidence from detrital zircon chronology", Journal of palaeogeography, vol. 16, no. 1, (2014), pp. 19-29.

[5] X. Wang, Y. Jiao, Y. Du, W. Ling and L. Wu, "REE mobility and Ce anomaly in bauxite deposit of WZD area, northern Guizhou, China", Journal of Geochemical Exploration, vol. 133, (2013), pp. 103117.

[6] D. Wang, P. Li, W. Qu, L. Yin, Z. Zhao, Z. Lei and S. Weng, "Discovery and preliminary study of the high tungsten and lithium contens in the Dazhuyuan bauxite deposit, Guihou, China", Science China: Earth Science, vol. 56, (2013), pp. 145-152.

[7] Y. Zhang, Y. Zhang, H. Wu, X. Y. Ding, W. Lin, Z. Lei and S. Wen, "Microscopic geochemical characteristics of oolite in oolitic bauxite ores from Wuchuan-Zheng'an-Daozhen area in the northern Guizhou province and their metallogenic significance", Geological science and technology information, vol. 32 , no. 1 , (2013), pp. 62-70.

[8] Y. Zhang, W. Lin, H. Wu, Y. Zhang and X. Ding, "Geochemistry of varied type ores of northern Guizhou bauxite and its implication for mineralization", Geological science and technology information, vol. 32, no. 1, (2013), pp. 71-79.

[9] Y. Du, Q. Zhou, Z. Jin and W. Lin, "Adcances in basic geology and metallogenic regularity study of bauxite in Wuchuan-Zheng,an-Daozhen area, northern Guizhou, China", Geological science and technonlogy information, vol. 32, no. 1, (2013), pp. 1-6.

[10] Z. Lei, S. Weng, Q. Cheng, X. Xiong, Z. Pan Z, X. He and H. Cheng, "Lithofacies paleogeography of the Dazhuyuan age, early Permian in the Wuchuan-Zheng'an- Daozhen area, northern Guizhou Province and its implication for bauxitisation”, Geological science and technology information, (2013), vol. 32, no. 1 , pp. 13-18.

[11] X. Huang, X. H. Zhang, Y. S. Du, Y. J. Qin and Z. Lei, "Age of bauxite forming in Northern Guizhou”, Geological science and technology information, vol. 32, no. 1, (2012), pp. 49-54.

[12] T. Cui, Y. Jiao, Y. Du, W. C. Yu, B. Ji, Z. Y. Lei, S. F. Weng, Z. G. Jin and S. Zhao, "Analysis on sedimentary characteristics and distribution features of bauxite in WuZhengDao Area, Northern Guizhou", Geology science and technology information, vol. 32, no. 1, (2013), pp. 52-56.

[13] T. Cui, Y. Jiao, Y. Du, X. M. Wang, Z. Y. Lei, S. F. Wang and Z. G. Jin, "Sedimentary palaeogeography and its mineralization significance of the early permain bauxite in Wuchuan-Zheng'anDaozhen area, northern Guizhou province", Journal of palaeogeographym, vol. 16, no. 1, (2014), pp. 918.

[14] Y. Du, Q. Zhou, Z. Jin, W. Lin, X. Wang and W. Yu, "Mineralization model for the early permian bauxite deposits in Wuchuan-Zheng,an-Daozhen area, northern Guizhou Province", Juornal of palaeogeography, vol. 16, no. 1, (2014), pp. 1-8.

[15] D. Du, J. Ren and Y. Wang, "Controlling of ancient karst hysiognomy on bauxite in northern Guizhou", Acta mineralogical Sinica, vol. 23, no. 4, (2007), pp. 473-476.

[16] P. Liu, "An additional discussion on bauxite deposits of Guizhou-Their metallogenetic epoch, material source and metallogenetic model", Geology of GuiZhou, vol. 10, no. 2, (1993), pp. 105-113.

[17] G. Bárdossy, "Karst bauxites, bauxite deposits on carbonate rocks", Developments in Economic Geology, (1990), pp. 320-332.

[18] Bushinsky, Bauxite Geology, Beijing, Geology Press, (1984), pp. 129-130.

[19] J. Gu, Z. Huang, H. Fan, Z. Jin, Z. Yan and J. Zhang, "Mineralogy geochemistry and genesis of lateritic bauxite deposits in the Wuchuan-Zheng'an-Daozhen area, northern Guizhou province, China", Journal of Geochemical Exploration, vol. 130, (2013), pp. 44-59.

[20] K. Yin, "Mineralization and metallogenic model for bauxite in the Wuchuan- Zheng'an-Daozhen Area, Northern Guizhou", Acta sedimentologica sinica, vol. 27, no. 4, (2009), pp. 452-457.

[21] W. Yu, Y. Du and S. Gu, "Multiperiod leaching process of early Permian bauxite in Wuchuan-Zheng'anDaozhen area, northern Guizhou province and its significance of ore-control", Geological science and technology in formation, vol. 32, no. 1, (2013), pp. 34-39. 


\section{Author}

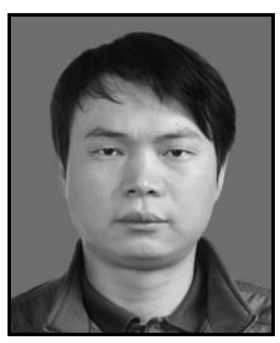

Tao Cui, He was born in1983, graduated from China University of geoscience in 2013 year, and the same year he got doctor degree of philosophy. Now he is an associate professor of Guizhou institute of technology, Guiyang, China. Regularity of ore formation and ore prediction is his research direction. 
International Journal of $u-$ and e- Service, Science and Technology Vol.9, No. 2 (2016) 